\title{
The Investigation of the Listening Strategies Teachers Instruct and the Listening Strategies Students Use
}

\author{
Lin, Yi-Hsiang \\ Chung Shan University, Taiwan \\ Huang, Yen-Ling \\ Department of Applied Foreign Languages, Chung Shan Medical University, Taiwan
}

\begin{abstract}
When people learn a new kind of language, the listening ability is the first ability people will encounter. Listening ability will also influence people to speak a new type of language fluently and correctly. This research aimed to determine the relationship between teachers' listening strategies and the listening strategies students use. Moreover, this research also intended to investigate what kind of listening strategies students usually use when practicing English listening. In this study, the researcher again examined the listening strategies teachers usually instruct during the class. The participants of the study were all freshmen of the Department of Applied Foreign Languages, University of central Taiwan with a certain level of English listening ability. The participants were going to fill out a questionnaire about their English listening habits. After analyzing the data, the researcher revealed final findings that indicated differences between teachers' listening strategies and the listening strategies students use. Teachers preferred to combine different materials and knowledge when they were in the listening class. Moreover, students tended to choose the materials that they are interested to improve their English listening after the course. Moreover, teachers also facilitate students with methods to enhance their English listening skills after class.
\end{abstract}

Index Terms - listening strategies, teachers' instruction, English learning

\section{INTRODUCTION}

\section{A. Background}

Listening plays a huge part in the process of people learning languages. Children make specific attempts to imitate words and speech sounds they hear around them (Brown, 2014). When it comes to learning a second language, listening ability seems to become much more critical. Listening skill is the main impetus to start in our first, second and foreign language learning process. Moreover, it is also a medium for communication to maintain the long and tedious learning process. (Bozorgian, 2012). Through listening to native speakers, learners improve their pronunciation of the target language. However, it seems to become a weakness of Asian students because they focus on improving their writing and reading abilities. Yet, teachers at school have been more concerned about how to improve the listening ability recently. Even though many language courses teach listening, experts still believe that teachers are encouraged to conduct much more research to make the teaching skills more effective (Selamat and Sidhu, 2011).

In general, listening strategies teachers instruct, such as listen to the keywords, the ability of prediction... etc., and listening strategies that students use are positively correlated (Bao, 2017). Besides, students could benefit from listening plans as these listening strategies assisted them in their academic success (Selamat and Sidhu, 2012). Listening strategies are the strategies that are used by non-native speakers in the process when they encounter the listening. Moreover, learners used the listening strategies when they learner the language that they are not familiar with. Overall, here are some common listening strategies that teachers teach: predict the content, listening for the gist, detecting the signposts, listening for details, and inferring the meanings.

Indeed, practical listening comprehension skills are essential for students' academic success (Selamat and Sidhu, 2012). However, it seems that it doesn't have many related articles which investigate English listening strategies between teachers' instruction and students' use. In Taiwan, there are still many students who struggle with English listening. Since teachers don't spend much time improving learners' listening ability, teachers in Taiwan focus more on English reading and writing abilities. Fortunately, recently people have increased the focus on the importance of English listening ability, and some schools even set up a course to teach students how to improve their listening ability. However, the studies of distinction between learner's English listening strategies use and teachers' strategies teach still remain few.

\section{B. Aims and the Purpose of the Study}

The researcher will let students have a more comfortable and more effective learning process during their second 
language acquisition period. The practical language learners apply the suitable strategies to achieve their learning target, however, ineffective language learners know a little in selecting and using strategies. (Chamot, Kupper and O' Malley, 1989).

During this study, the researcher focused on two points: 1.) the listening strategies teachers taught and the listening strategies that the students used.2.) the using frequency of meta-cognitive Strategy, Cognitive Strategy, and Social/affective Strategy.

Through the questionnaire designed in this study, the researcher aimed to answer the following questions:

1.) Teachers instruct and students' most used and least used strategy of the meta-cognitive process.

2.) Teachers teach and students' most used and least used strategy of cognitive strategy.

3.) Teachers instruct and students' most used and least used strategy of the social/affective strategy.

4.) What is the relationship between the listening strategies teachers teach and the strategies that students use?

\section{Significance of This Study}

This study provides some data on students' listening strategies currently and discovers the effective listening strategy when people are learning a second language. Besides, the researcher will also find out some listening strategies that teachers taught during the class. By computing these data, the researcher can discover helpful listening strategies to improve learners' listening ability. Hopefully, during this study, research suggested some beneficial methods to enhance learners' listening ability when they are in the second language acquisition process.

\section{LITERATURE REVIEWS}

\section{A. Listening Comprehension}

Listening comprehension is just an input and passive activity which involves a complicated and active process. During this process, the listener must distinguish sounds, understand vocabularies and grammatical structures, solve stress and intonation, preserve all the things above. Besides, we must interpret it under the immediacy and the more significant social background utterance. (Vandergrift, 1999). In the second language theory, listening to the spoken language has been admitted as the combination of active and involved processes that decide the content and understanding level (Chamot, Kupper, and O' Malley, 1989). Under the presentation of comprehensive channels, the accomplishment in listening is measured by the proper response to the questions or tasks. Field (1998) claimed that teachers focus on the result of listening instead of listening to themselves. In this theory, listening comprehension is considered as a joyful process. People focus on selecting the aural input aspect, constructing meaning from a passage, and related things they heard to the current knowledge. (Chamot, Kupper, and O' Malley, 1989). According to River (1996), listening to a foreign language may be analyzed as involving two levels of activities. First is the recognition level, which involved identifying the structural inter-relationship between the words and phrases, time sequences, logical and modifying terms, and unnecessary interpolation phrases, increasing nothing to develop sentences. And second is the level of selection that listeners draw out from the communication. These components include the main point of the message. This process asks listeners to focus on specific sound grouping while other people are aurally perceived without being preserved. (River, 1996).

\section{B. Listening Strategies}

According to the western study of foreign language, listening comprehension strategies consider the learning strategies as their theoretical framework. As a result, many researchers seek listening comprehension strategies as learning strategies (Bao, 2017). Chatom (1987) points out that learning strategies are skills, approaches, or deliberate actions that students take to boost learning and recall linguistic and content information (Bao, 2017). Chamot and O'Malley (1990) have categorized the language learning cognitive activity range into two main styles: metacognitive and cognitive strategies. Metacognitive strategies are the strategies that supervise, control or instruct the process of language learning. Metacognitive strategies are related to the learning process's thinking, which includes designing, monitoring, and assessing. But without deploying the proper cognitive strategies, the approach of metacognitive strategies will be eliminated. Cognitive strategies operate the learning material or utilize a particular skill in the learning mission. Besides, they have added the third category, socio-affective strategies, to talk about the collaboration between the language learner and classmates, asking the teacher's clarification, or using specific skills to make them less anxious. (Vandergrift,1999). The cognitive strategies are different from other learning strategies. These are activities which learner apply to comprehend the language input and receive knowledge. (Boroujeni, Hesabi, and Serri, 2012).

\section{Related Studies}

According to the study that Bao (2017) conducted, the author designed a questionnaire for 174 non-English majors and 35 teachers from the College English Department in a University and collected 170 and 34 valuable questionnaires. And the conclusion that this study carried out the correlation between the strategies that teachers guide and the strategies that students use are correlated positively. However, the applying of the social/affective strategy has an interval. Teachers pay the same attention to both cognitive and social/affective strategies. In contrast, students do not use social/affective very often. The deploying of listening strategies and learning style can become a predictor of 
listening ability because they have a statistically significant relationship (Liu, 2008). Also, through the research which Tuan (2012) conducted, the study shows that teaching students' speaking performance and measuring students' speaking performance should be a process rather than a product. The study contrasts the whole present preferable scoring way in teaching and evaluating learners speaking ability. The entire scoring way can benefit teachers in both education and assessing students' articulating display. The emphasis on listening comprehension and listening strategies can help students take advantage of the language input and attain massive success in language learning (Vandergrift,1999).

\section{METHODOLOGY}

\section{A. Participants}

The 44 freshmen of the Applied Foreign Language department of Chung Shan Medical University were invited to participate in this research as the experimental group. These 44 students are all with a certain level of English. And all of them are having over five years or more English learning experience.

\section{B. Instruments}

The questionnaire attached at the end of this study (see Appendix) was based on Bao's questionnaire in 2017. The questionnaire is mainly divided into three parts. The first part is about the demographic of participants. The second part centers on listening strategies that students used, and the third part is the listening strategies teachers teach. The researcher also divided the first part, the listening strategies students used, into three sections. 1.) Meta-cognitive Strategy 2.) Cognitive Strategy 3.) Social/affective Strategy. And the researcher will give each section five questions. There are 15 questions for the first part in total. As the second part of the questionnaire, the researcher also categorized it into three parts. 1.) Meta-cognitive Strategy 2.) Cognitive Strategy 3.) Social/affective Strategy. Part 1 and 2 are five questions, respectively, However, the third part -- Social/affective Strategy only include one question. There are 11 questions for the second part in total. The researcher used the 4-point Likert scale ranging from 1 - strongly disagree to 4 - strongly agree to measure participants' opinions. Two foreign language department professors had already filled out this questionnaire and modified the inappropriate item to consider its content validity.

\section{Procedures}

For the first step, we were going to select 44 first-year students to fill out the questionnaire. The researcher's standards to choose participants are 1.) students who have a similar level of English ability 2.) students who are having an equivalent length of time 3.) students who are learning English in a similar background. After collecting all 44 questionnaires, the researcher applied the online statistic software - the SPSS to compute the data and analyze the results.

\section{Research Execute Flow Chart}

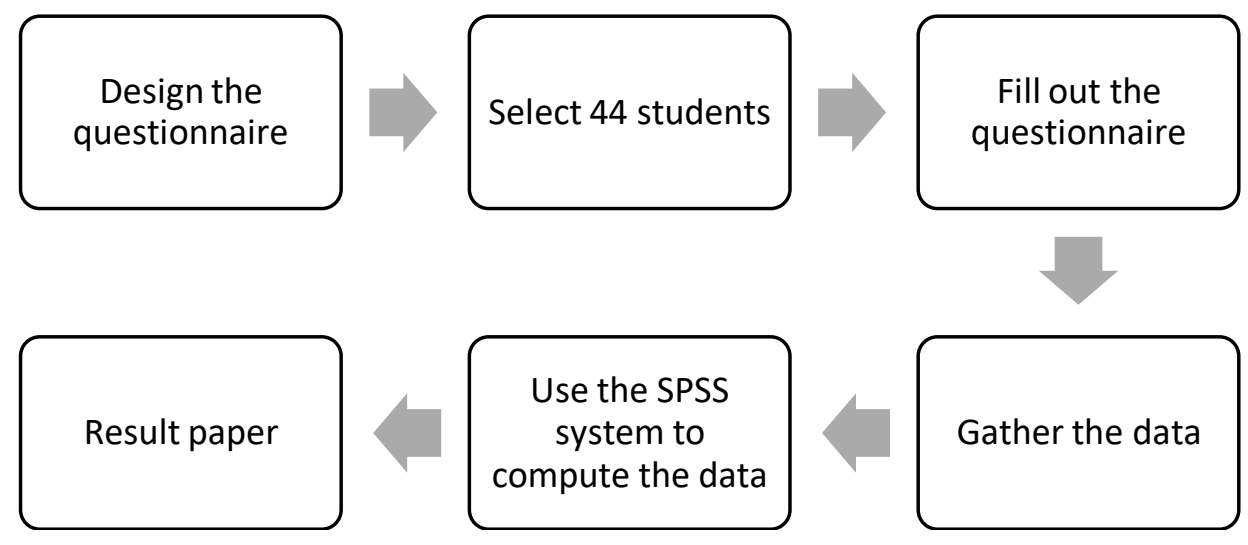

\section{E. Data Analysis}

In this study, the researcher used the SPSS as the analysis tool. Also, the researcher printed the questionnaires and sent them to each participant. After the participants finished the questionnaire, the researcher collected the questionnaire. To reveal the valid and visible results, the researcher made a chart to analyze the data.

\section{F. Expected Result}

This study's expected result is that the students can realize helpful listening strategies after answering the questionnaire. Besides, after collecting and computing the data, the researcher can determine the listening strategies students and teachers frequently use and find out the most useful listening strategies. The result of this can also resolve the solution to improve the weakness of students' listening ability and also increase their desire to learn English. 


\section{RESULTS AND DISCUSSION}

\section{A. The Descriptive Demographic Statistic}

The questionnaire had been filled by 44 freshmen of the department of Applied Foreign Languages. There are 9 male students and 35 female students in total who had done this questionnaire. And with the $63.4 \%$ of students spend over 5 hours on studying English per week. However, only 36.6\% of students spend over 10 hours learning English per week.

\section{B. The Descriptive Statistics of the Students' Listening Strategies}

TABLE 1.

THE OVERALl SituATION OF STUDENTS’ Listening STRATEGIES

\begin{tabular}{llc}
\hline Name of the strategy & Mean & Standard Deviation \\
Meta- cognitive strategies & 3.5091 & .4926 \\
\hline Cognitive strategies & 3.9227 & .5822 \\
Social/ affective strategies & 3.6181 & .6885 \\
Overall strategies & 3.6833 & .5878 \\
\hline
\end{tabular}

Table 1 indicated that the most listening strategy students used are the cognitive strategies (mean 3.92). But in fact, the students' frequency to use these three strategies didn't show a huge difference. The least used strategy by students is the meta-cognitive strategy (mean 3.50). Overall, the mean value of strategies is 3.68, which stays high but higher than the average mean. Compared with the previous studies made by Bao (2017), the overall strategies' mean value of this study (mean 3.68) is higher than the 2.9449 mean value that Bao's research.

1. Students' most used and least used strategy of the meta-cognitive strategies

TABLE 2

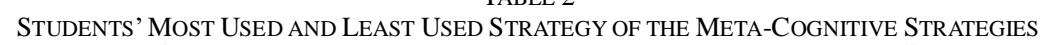

\begin{tabular}{lcc}
\hline Questions & Mean & Standard Deviation \\
Question 1 & 4.30 & .632 \\
\hline Question 2 & 2.57 & .998 \\
Question 3 & 4.00 & 1.078 \\
Question 4 & 3.41 & .923 \\
Question 5 & 3.27 & .872 \\
\hline
\end{tabular}

Table 2 indicated that the most used strategy of the meta-cognitive strategies is question 1, "when students find mistakes that they made during the listening process, they will try to find out the reasons," which mean value was 4.30 . The result was in light of a study that Bao (2017) made, indicating that contemporary college students' self-regulation awareness is vital (Bao, 2017). And the least used metacognitive strategy is question 2, "the students will skip the new words or difficult sentences when they were listening to English," which only has a 2.57 mean value. The second most used strategy is question 3, "they will try to understand every word when they were listening to English," which has a 4.00 mean value in this question. This data showed that students preferred to find out the problems they encountered during the listening process and figured out why they had made these mistakes (question 1). Moreover, they would like to understand every word that the speaker is talking about (question 3), which means students do not want to skip the difficult words or sentences when listening (question 2). In contrast, students' frequency of practicing listening (question 5) or reviewing the listening materials after class (question 4) is relatively low, with only 3.27 and 3.41 mean values.

2. Students' most used and least used strategy of the cognitive strategies

TABLE 3

\begin{tabular}{ccc} 
STUDENTS' MOST USED AND LEAST USED STRATEGY OF THE COGNITIVE STRATEGIES \\
\cline { 2 - 3 } Questions & Mean & Standard Deviation \\
Question 1 & 3.68 & 1.157 \\
\hline Question 2 & 4.11 & .841 \\
Question 3 & 3.93 & .950 \\
Question 4 & 3.52 & 1.171 \\
Question 5 & 4.36 & .865 \\
\hline
\end{tabular}

According to Table 3, we can understand that the most used strategy of the cognitive strategy is question 5, "by watching the English movies and series, students can often learn the real and national English information", with a 4.36 mean value. Through this result, we predicted that students can improve their English ability by taking classes and sometimes prefer to practice their English in a more comfortable way, such as listening to music and watching English series or movies. Many studies offered powerful finding showing that movies benefit both listening and speaking in the learners' language performance (Chung, 1999; Lin, 2002; Weyers, 1999; Chen, 2012). Moreover, it is a readily available method for students to access in their daily life. And the least used strategy is that "students prefer to translate the word that they have heard into Chinese during the listening process "(question 4), which is 3.52 mean value. As the second 
most used strategy is the strategy that "students will take notes during the process of listening, and will also try to write down every important information" (question 2), which is 4.11 mean value. As we can see, students' frequency of using the cognitive strategy is much higher than the frequency that students use the meta-cognitive strategy.

Moreover, students tend to use other materials to get closer to accurate and local English information (question 5). Besides, students are more likely to take notes when they are in the listening process (question 2). And after the class, they would like to categorize the words they have learned during the course to make them memorize the words easier (question 3). But they won't remember the new terms by connecting the pronunciation with the Chinese words (question 1) or translate every English word into Chinese during the listening process (question 4). Students' most used and least used strategy of the social/affective strategies

TABLE 4

\begin{tabular}{|c|c|c|}
\hline Questions & Mean & Standard Deviation \\
\hline Question 1 & 4.57 & .094 \\
\hline Question 2 & 3.41 & 1.109 \\
\hline Question 3 & 3.70 & .878 \\
\hline Question 4 & 3.23 & .985 \\
\hline Question 5 & 3.18 & 1.225 \\
\hline
\end{tabular}

From Table 4, we learned that the most used strategy of the social/ affective strategy in which "students will choose the ways that they like to study English after class, for example, listening to music, and watching TV program (question 1)", with 4.57 mean value. Watching English movies and series can improve our vocabulary and listening comprehension and increase students' reading and comprehension speed (Sabouri and Zohrabi, 2015). As the least used strategy is question 5, "students like to find out several partners to learn together," with only a 3.18 mean value. According to Bao (2017), he categorized this strategy into cooperative learning and said that students often neglect the strategy. Because Taiwanese schools did not emphasize that students should find a partner to help them in the learning process or encourage students to find a partner to learn with, students prefer to learn things on their own. Students were considered this process as acquiring knowledge of language rather than communicative ability directly, and they just received the new knowledge passively (Zhang, 2010). And the second used strategy was "students not only question themselves about the problems that they cannot understand but also through the question they made to get more information from the speaker (question 3)", with a 3.70 mean value. According to the questionnaire result, students learned by themselves, using the material they like to improve their listening ability (question 1).

Furthermore, they reflected on the question they do not understand and their mistakes (question 3). Through the questionnaire, we also know that students' level to study in a group or discuss with others (questions 4 and 5) was lower than learning by themselves. Moreover, students' frequency to questions English communication with their classmates or teachers was the second least used strategy in the social/affective strategy (question 4). Compared with the strategies ahead, the social/ affective strategy stayed in the central place of students' frequency.

\section{The Descriptive Statistic of Teachers Instruct Listening Strategies}

TABLE 5

THE OVERALL SitUATION OF TEACHERS INSTRUCT LISTENING STRATEGIES

\begin{tabular}{llc}
\hline Name of the strategy & Mean & Standard Deviation \\
Meta- cognitive strategies & 3.9000 & .6015 \\
\hline Cognitive strategies & 3.8681 & .5437 \\
Social/ affective strategies & 3.9300 & .9250 \\
Overall strategies & 3.8993 & .6901 \\
\hline
\end{tabular}

Table 5 indicated students think that the frequency of the listening strategies that teachers instruct during the class (mean 3.89) was slightly higher than the frequency that students used listening strategies on their own (mean 3.68). And the frequency that teachers use each strategy was very close with each strategy. After analyzing, the author listed the most used and least used strategies of each strategy. The most used strategy of the meta-cognitive strategy was that the teacher often combines listening and speaking during the listening class. The use of language can assist language learning. By using language, the received information can leave a more profound impression on the brain (Bao, 2017).

1. The most used and least used meta-cognitive strategies that teacher instruct

TABLE 6

The Most Used and Least Used Meta-Cognitive StRategies That Teacher Instruct

\begin{tabular}{lll}
\hline Questions & Mean & Standard Deviation \\
Question 1 & 3.09 & 1.309 \\
\hline Question 2 & 3.95 & .806 \\
Question 3 & 4.48 & .731 \\
Question 4 & 3.98 & .762 \\
Question 5 & 4.00 & .747 \\
\hline
\end{tabular}


The data in Table 6 showed the most used strategy teachers instruct was question 3, "during the listening class, the teacher often combines the listening and speaking," which has a 4.48 mean value. And the least used strategy that teachers instruct is "during the listening process when the students encounter difficult words or sentences; the teacher will guide the students skip them and continue the following listening (question 1)", with only 3.09 mean value. And the second most used strategy that teachers instruct is that "before the students start listening, the teacher helped the students figure out the listening process (question 5)". And this question has a 4.00 mean value. As a result, we can find out that teachers prefer to teach listening and speaking skills during the listening class (question 3), and this process can help students have a better language learning result. By combining the listening and speaking skills, the brain can have a more profound impression of these two skills. Students can seize the same information instantly when they listen to it next time. On the same level, students think it is tough to enhance their listening ability because they lack the occasion to practice speaking (Bao, 2017).

Moreover, teachers will lead students to think about the purpose of the listening before they start the listening (question 5) and instruct students with different listening skills according to the other materials they use (question 4). But teachers won't skip those problematic words or sentences during the listening process (question 1), which is similar to the strategy students use in the meta-cognitive strategy. Teachers' frequency of instructs on the meta-cognitive is close to how teachers instruct the cognitive strategy.

2. The most used and least used cognitive strategies that teacher instruct

TABLE 7

\begin{tabular}{ccc} 
THE Most UsED AND LEAST USED COGNITIVE STRATEGIES THAT TEACHER INSTRUCT \\
\cline { 2 - 3 } Questions & Mean & Standard Deviation \\
Question 1 & 4.18 & .724 \\
\hline Question 2 & 4.00 & .835 \\
Question 3 & 3.64 & 1.104 \\
Question 4 & 4.22 & .784 \\
Question 5 & 3.41 & 1.064
\end{tabular}

As we can see in Table 7, question 1 was the most used strategy that teachers instruct, "teachers will teach the students new knowledge and understand the listening materials by connecting the old and new knowledge." This strategy has a 4.18 mean value. As the least used strategy is that "teachers will remind students not to translate every single word into Chinese during the listening process" (question 5), with a 3.41 mean value. And the second most used strategy is "during the process of listening, the teachers will let the students write down the information they think. Before and after the listening, teachers let students discuss how to take note "(question 4). It has a 4.11 mean value with it. According to the result, the author inferred that teachers emphasized connecting new and old knowledge during their teaching process (question 1). They also focused on predicting the content throughout reading the title and questions to be answered (question 2) and how students take notes during the reading process (question 4). Teachers avoid to disturbing students in the listening process (questions 3 and 5).

3. The most used and least used social/affective strategies that teacher instruct

TABLE 8

The Most Used AND Least Used Social/AFFECTIVE STRATEGIES THAT TEACHER InSTRUCT

\begin{tabular}{llc}
\hline Questions & Mean & Standard Deviation \\
\hline Question 1 & 3.93 & .925 \\
\hline
\end{tabular}

The mean value of the only question of the social/ affective is 3.93, which stayed at a high level compared with other questions that the author provided in the questionnaire. And this showed that teachers are willing to guide students to find out the methods which they are interested in to improve their English ability.

D. The Pearson Correlation Coefficient of the Strategies that Teachers Instruct and Students Used

TABLE 9

THE PEARSON CORRELATION COEFFICIENT OF THE STRATEGIES THAT TEACHERS INSTRUCT AND STUDENTS USED

\begin{tabular}{lcccc}
\hline & & mean value & Pearson's r & the significant \\
\hline meta-cognitive & students & 3.5091 & .298 & \\
strategies & teachers & 3.9000 & 1 & .057 \\
cognitive strategies & students & 3.9227 & 1 & \\
& teachers & 3.8681 & .455 & .002 \\
social/affective & students & 3.6181 & .104 & \\
strategies & teachers & 3.9300 & 1 & .501 \\
\hline
\end{tabular}

As we can see above, the significance of the cognitive strategies that teachers instructed and the students used is 0.002 (under 0.05), which means the relationship between the cognitive strategies that students used and teachers 
instruct is strong. For the students, the cognitive is also the most used strategy in the listening learning process. Both teachers and students did not prefer to translate English into Chinese during the listening process. Moreover, taking notes and writing down the important is the strategy that teacher and students tend to do while listening to English. And these two strategies are the least used and most used strategy that both teachers and students apply in cognitive. As the significance of the social/ affective strategies is 0.501 (above 0.05), the least correlation of the three strategies, which interestingly happened to be the teacher's most instruct strategy. Choosing the students' learning methods is how students and teachers would like to use them in the social/ affective strategy. The significance of meta-cognitive is 0.057 , which stays in the middle of the three strategies. Skipping the words and sentences is the least likely strategy for both teachers and students when applying the meta-cognitive strategy.

\section{CONCLUSION}

This study aimed to investigate the most and least used listening strategies students use during the listening process and the most and least listening strategies teachers instruct when teaching the listening class. The conclusions of this study addressed into two parts. First, students used the three listening strategies to stay at a medium level (mean 3.68), and there is no huge gap between them. The frequency of students utilizing the listening strategies from the highest to the lowest was cognitive strategy (mean 3.92), social/affective strategy (mean 3.61), and meta-cognitive strategy (mean 3.50). In cognitive strategy and social/ affective strategy, we found out that students use the materials given by teachers and seek other materials such as listening to music and watching movies to improve their English listening ability. Moreover, students use some listening strategies to classify and categorize conversation during the listening classes, which can help them learn vocabulary efficiently and understand the listening content more clearly. In addition, the listening process, when students find out the mistakes, they try to figure out the reasons and correct answers.

Secondly, the overall listening strategies that teachers instruct also stay at a medium level (mean 3.89). And it is a little bit higher than the frequency that students used the listening strategies. The frequency that teachers instruct the listening strategy from high to low was social/affective strategy (mean 3.93), meta-cognitive strategy (mean 3.90), and cognitive strategy (mean 3.86). As we can find out in the result, teachers intended to assist students with the methods they are interested to improve their English listening ability. In addition, teachers also combine the previous knowledge and the new knowledge to teach students during the listening classes. Besides, listening is not only the skill teachers teach during the listening class; whereas, teachers integrate speaking skills during the lessons.

The teaching implication:

According to the result of the meta-cognitive strategy that students used, we can find out that students put less emphasis on practice listening after classes (mean 3.27) and review the teaching materials after class. Therefore, teachers can reinforce students to practice more English listening skills after class. For example, teachers can assign English songs or English videos without subtitles after classes. Besides, teachers can also facilitate students to build the habits of reviewing the teaching material after class. Moreover, the using frequency of classifying and categorizing the words that students have learned before stays at a relatively low level (mean 3.93), teachers can demonstrate how to organize and associate the knowledge they have known before. Also, students are not willing to find a partner to learn together (mean 3.18) which indicated students did not like to share some information with their teachers and classmates (mean 3.23). Therefore, teachers can try to encourage students to find a partner to reinforce cooperative learning. It also helps students cultivate the habit of sharing their ideas and information with their classmates and teachers to promote collaborating learning.

\section{APPENDIX}

\section{Questionnaire of the investigation of the listening strategies teachers instruct and the listening strategies students use}

This questionnaire is completely anonymous. And the purpose of this questionnaire is about to study if the students are using the listening strategies or not, also the researcher is going to study if the teachers in school are teaching listening strategies or not. There are three main parts of this questionnaire, please read the questions carefully and complete the following questionnaire to the best of your ability. Thank you for your cooperation.

\section{Part I Demographics}

1. Gender: __ Male _ Female

2. what is the regular hours you spend on English study per week

\section{Part II The listening strategies that students used}

Please read the questions carefully and using the following scale:

1 = strongly disagree, $2=$ disagree, $3=$ agree, $4=$ strongly agree

1.) Meta-cognitive Strategy 
1. When I find mistakes that I made during the listening process I will try to find out the reasons.

2. I will skip the new words or difficult sentences when I was listening to English.

3. I will try to understand every word when I was listening to English.

4. I will review the listening materials in my planned way after class.

5. I do a lot of reading and listening practice after class in order to improve my listening ability.
$\begin{array}{llll}1 & 2 & 3 & 4\end{array}$
$\begin{array}{llll}1 & 2 & 3 & 4\end{array}$
$\begin{array}{llll}1 & 2 & 3 & 4\end{array}$
$\begin{array}{llll}1 & 2 & 3 & 4\end{array}$
$\begin{array}{llll}1 & 2 & 3 & 4\end{array}$

2.) Cognitive Strategy.

1. I will try to remember every new English word by relating them with the pronunciation of Chinese words during the listening process.

2. I will take notes during the process of listening. And I will also try to write down every important information.

3. I will classify and categorize the words that I have learned after class.

4. I prefer to translate the words that I have heard into Chinese during the listening process.

5. By watching the English movies and series, I can often learn the real and national English information.

$\begin{array}{llll}1 & 2 & 3 & 4\end{array}$

$\begin{array}{llll}1 & 2 & 3 & 4\end{array}$

$\begin{array}{llll}1 & 2 & 3 & 4\end{array}$

$\begin{array}{llll}1 & 2 & 3 & 4\end{array}$

$\begin{array}{llll}1 & 2 & 3 & 4\end{array}$

3.) Social/affective Strategy

1. I will choose the ways that I like to study English after class, for example, listening to music, and watching English tv program.

2. When I met some difficult problems during the listening process, I will consult with my teachers and classmates.

3. I am not only question myself about the problems that I can't understand but also through the question that I made to get more information from the speaker.

4. I will often communicate with teachers, classmates to share some information with them, and also test the learning effects of myself at the same time during the listening study.

5. I like to find one or several partners to learn together.

$\begin{array}{llll}1 & 2 & 3 & 4\end{array}$

$\begin{array}{llll}1 & 2 & 3 & 4\end{array}$

$\begin{array}{llll}1 & 2 & 3 & 4\end{array}$

$\begin{array}{llll}1 & 2 & 3 & 4\end{array}$

$\begin{array}{llll}1 & 2 & 3 & 4\end{array}$

\section{Part III The listening strategies that teacher used}

Please read the questions carefully and using the following scale: 1 = strongly disagree, 2 = disagree, 3 = agree, $4=$ strongly agree

1.) Meta-cognitive Strategy

1. During the listening process, when the students encounter difficult words or sentences, the teacher will guide the students skip them and continue the following listening.

2. The teacher will let the students classify and categorize the words that they have learned before.

3. During the listening class, the teacher often combine the listening and speaking.

4. The teacher will guide the students to use different listening skills according to the different listening materials.

5. Before the students start listening, the teacher will let the students figure out the listening purpose.
$\begin{array}{llll}1 & 2 & 3 & 4\end{array}$
$\begin{array}{llll}1 & 2 & 3 & 4\end{array}$
$\begin{array}{llll}1 & 2 & 3 & 4\end{array}$
$\begin{array}{llll}1 & 2 & 3 & 4\end{array}$

2.) Cognitive Strategy 
1. The teacher will not only teach the students new knowledge, but also understanding the listening materials by connecting the old and new knowledge.

2. Before start listening, the teacher will let students predict the content by the title and the questions to be answered.

3. During the listening process, the teacher will sometimes pause the listening and let the students to predict the following content by the contents above.

4. During the process of listening, the teacher will let the students write down the information they think. And before and after the listening, the teacher will let students discuss how to take notes.

5. The teacher will remind students not to translate every single word into Chinese during the listening process.
$\begin{array}{llll}1 & 2 & 3 & 4\end{array}$
$\begin{array}{llll}1 & 2 & 3 & 4\end{array}$
$\begin{array}{llll}1 & 2 & 3 & 4\end{array}$
$\begin{array}{llll}1 & 2 & 3 & 4\end{array}$
$\begin{array}{llll}1 & 2 & 3 & 4\end{array}$

3.) Social/affective Strategy

1. The teacher will guide the students to choose the methods that they are interested in to learn English. For example, listening to music, and watching English movie, etc.

\section{REFERENCES}

[1] Bao, X. (2017). A Study on Listening Strategies Instructed by Teachers and Strategies Used by Students. International Journal of English Linguistics; 7(2) pp. 186-195.

[2] Boroujeni, A. J, \& Hesabi, A, \& Serri, E. (2012). Cognitive, Metacognitive, and Social/Affective Strategies in Listening Comprehension and Their Relationships with Individual Differences. Theory and Practice in Language Studies, 2(4), pp. 843-849.

[3] Bozorgian, H. (2012). The Relationship between Listening and Other Language Skills in International English Language Testing System. Theory and Practice in Language Studies, 2(4), pp. 657-663.

[4] Brown, H. D. (2014). Principles of language learning and teaching. The United States of America: Person Education, Inc.

[5] Chamot, A. U. (1987). Learning strategies of ESL students. In Wenden (Ed.), Learner Strategies in Language Learning. Great Brain: Prentice Hall. pp. 71-83.

[6] Chamot, A. U, \& Kupper, L, \& O’ Malley, J. M. (1989). Listening Comprehension Strategies in second language acquisition. Applied Linguistics, 11(4), pp. 418-437.

[7] Chamot, A. U, \& O' Malley, J. M. (1990). Learning strategies in second language acquisition. Cambridge University Press.

[8] Chen, M. L. (2012). Effects of integrating children's literature and DVD films into a college EFL class. English Teaching: Practice and Critique, 11 (4), pp. 88-98.

[9] Field, J. (1998). Skills and strategies: towards a new methodology for listening. ELT Journal 52(2), pp. 110-118.

[10] Liu, H. J. (2008). A Study of The Interrelationship Between Listening Strategy Use, Listening Proficiency Levels, And Learning Style. ARECLS, Vol.5, pp.84-104.

[11] Rivers, W. M. (1966). Listening Comprehension. The Modern Language Journal, 50(4), pp.196-204.

[12] Sabouri, H, \& Zohrabi, M. (2015). The Impact of Watching English Subtitled Movies in Vocabulary Learning in Different Genders of Iranian EFL Learners. International Journal on Studies in English Language and Literature (IJSELL), 3 (2), pp. $110-125$.

[13] Selamat, S, \& Sidhu, G.K. (2011). Student Perceptions of Metacognitive Strategy Use in Lecture Listening Comprehension. Language Education in Asia, 2(2), pp.185-198.

[14] Selamat, S, \& Sidhu, G.K. (2012). Enhancing Listening Comprehension: The role of Metacognitive Strategy Instruction (MetSI). Procedia-Social and Behavioral Sciences 90, pp.421-430.

[15] Vandergrift, L. (1999). Facilitating second language listening comprehension: acquiring successful strategies. ELT Journal, 5(3). pp. 168-176.

[16] Zhang, Y. (2010). Cooperative language learning and foreign language learning and teaching. Journal of Language Teaching and Research, 1(1), pp. 81-83

Lin, Yi-Hsiang is an undergraduate student of AFL in Chung Shan University. Her interests are in the field of teaching English as second language (TESL) and second language acquisition (SLA) studies. She currently revived MOST subsidies for undergraduate research projects and has presented articles in the conference.

Huang, Yen-Ling is associate professor in the Department of Applied Foreign Languages at Chung Shan Medical University in Taiwan. Her research interests include CALL, TESL, second language acquisition and language teaching and learning. She is the member of the curriculum development at CSMU and Taiwan ESP Association. 